Journal of Research in Interprofessional

Practice and

Education

Vol. 1.1

November, 2009

Internet Devices and Desires:

\title{
A Review of Randomized Controlled Trials of Interactive, Internet-mediated, In-home, Chronic Disease Monitoring Programs
}

\author{
Anne-Marie Nicol, PhD; Corlann Gee Bush, MSAS; \\ Ellen Balka, PhD
}

\begin{abstract}
Background and Objectives: The advent of the Internet has made in-home monitoring a possibility for patients suffering from chronic disease, although few studies have examined this phenomena across different disease states. The goal of this review is to identify and evaluate studies where randomized control trials were used to evaluate Internet-mediated home monitoring systems designed to manage and support patients with chronic diseases.

Methods and Results: We reviewed 454 abstracts of articles describing computerbased health interventions and read forty-three articles in depth. Seventeen articles met inclusion criteria and were selected for this review. Only completed randomized, controlled trials that reported physiological health outcomes of the intervention were included. Other results reviewed included the populations studied, the short and long term effectiveness of the interventions, costs and technology-related issues and health care provider communication. Internet-mediated home monitoring interventions appear to have some benefit for specific chronic diseases in specific circumstances. Few studies documented cost savings; none of those that did used consistent measures. Studies seldom addressed the challenges of introducing sophisticated interactive-monitoring systems into patients' homes, the reasons for attrition from trials, or the effects of the intervention on the work of care providers or interprofessional practices.

Conclusions: The interventions reviewed showed potential to enhance chronic disease management in some cases. However, the short duration of the studies made it difficult to generalize the results to wider home care settings or predict the effectiveness of such systems over the long and complicated courses of chronic diseases. Thus, despite hopes for significant cost and labour savings, Internet-mediated systems for monitoring chronic diseases in patients' homes will likely complement rather than replace usual care.
\end{abstract}

Keywords: Internet; Chronic disease; Outcomes assessment; Disease monitoring; Randomized controlled trials; Home monitoring; Cost/benefits

\section{Journal of Research in Interprofessional Practice and Education (JRIPE) \\ Vol. 1.1 \\ (C) 2009 \\ Corresponding author: Anne-Marie Nicol \\ Email:

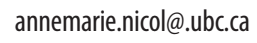

\section{Introduction}

The World Health Organization estimates that, worldwide, chronic diseases are responsible for $60 \%$ of deaths per annum [1]. In Canada, chronic health conditions affect one in three Canadians, cost the Canadian economy 80 billion annually [2], and pose significant challenges to providers and the healthcare system as well as patients and their families. Both the incidence and costs of chronic diseases are expected to increase due to the aging of the population and the rise in correlated risk factors such as obesity and inactivity. 
68

The Role of the Internet in Homebased Patient Monitoring

Nicol, Bush, \& Balka

Journal of Research in Interprofessional Practice and Education

Vol. 1.1

October, 2009
Although chronic diseases are costly to treat, they can be among the most manageable diseases affecting large segments of the population. The Health Council of Canada (HCC) has identified the following elements of "good" chronic disease management in their 2006 Annual Report [3]. These include identifying patients with chronic disease, having access to data on individuals and populations through highquality information systems, organizing patients by risk and involving patients in their own care. Also included in "good disease management" are using case managers to coordinate care, using interprofessional teams, integrating specialist and generalist expertise, minimizing unnecessary visits and admissions and providing care in the least intensive setting.

While there are many ways to approach chronic disease management, government studies such as the Romanow Report [4] suggest that meeting the HCC management guidelines can be facilitated through the use of new and emerging health information technologies. Fortuitously, while the incidence of chronic disease and cost of treatment continue to grow, the costs of new technologies such as computers, personal data devices, and Internet and wireless connections are falling, the technologies are becoming easier to use, and people are willing to use them for health-related purposes. Indeed, of the 6.7 million people in Canada who have access to the Internet from their homes, over half (58\%) already access health information online [2].

New health information technologies make it possible for patients to participate in managing their chronic diseases in their own homes. Internet-enabled home monitoring systems have the potential to integrate a wide variety of peripheral devices (visual displays and enhanced video monitoring) and functions (graphs and charts) into the care of chronically ill patients [5]. Thus, Internet-mediated home monitoring systems could help providers meet several of the objectives for chronic care management set out by the Health Council of Canada, most notably facilitating the use of interprofessional care teams in a manner that is independent of geography and may be relatively cost-effective. Internet technologies could also offer patients greater involvement in their own care, fewer clinic visits, and care in the least intensive settings.

Unfortunately, relatively little is known about the overall effectiveness of using the Internet as a platform for home-based monitoring of chronic diseases or how these platforms may facilitate team approaches to patient management. Since 2004, the Cochrane Collaboration has examined studies of a wide variety of Internetbased, interactive tools such as educational CDs, support groups, Internet therapies, and monitoring systems [6]. Other reviews have focused on specific diseases and examined the effectiveness of a wide variety of monitoring systems ranging from older telephone-based platforms to Internet and cellular technologies [7,8,9]. No one, to our knowledge, has concentrated a review specifically on chronic diseases, looked at health outcomes as a common measure of effectiveness, or focused specifically on the role of the Internet in health interventions.

We set out to identify randomized controlled trials (RCTs) that reported on the use of the Internet as a platform for the transmission of health information to and from 
69

The Role of the Internet in Homebased Patient Monitoring

Nicol, Bush, \& Balka

Journal of Research in Interprofessional Practice and Education

Vol. 1.1

October, 2009 chronically ill patients. In particular, we were interested in trials that studied the effectiveness of Internet-based systems that were deployed in patients' homes and that analyzed the effect of the intervention on patients' health outcomes. By including a range of chronic diseases, we wanted to comment on the usefulness of the Internet across a spectrum of different illnesses and by a range of healthcare professionals. Further, by looking at a collection of studies that had several elements in common-the platform for delivery, a concern with health outcomes, and a focus on chronic disease management-we hoped to draw conclusions about the potential overall benefits and shortcomings of using Internet-based devices for home health monitoring.

\section{Methodology}

We conducted a systematic search of the literature to identify RCTs that used the Internet as a platform in home monitoring interventions for the management of specific chronic diseases. Only completed RCTs were considered, thus excluding pilot studies and descriptive mid-study reports $[10,11,12]$.

\section{Definitions}

Because there is no widely accepted terminology for the types of Internet-mediated home monitoring devices we wanted to study, we developed our own definitions for both interactive and Internet-mediated monitoring systems the purposes of this project.

Interactive means that the disease monitoring system included elements through which patients provided information about the status of their diseases to a healthcare provider and the provider fed information back to the patient. The term thus differentiated a) systems through which patients collect and transmit data and receive feedback from b) stand-alone systems in which patients record data and monitor their own progress but do not receive feedback from a healthcare professional. However, feedback to the patient did not necessarily need to be provided via the Internet, but could have taken the form of telephone calls, meetings, and clinic or home visits. Nor did it have to occur immediately upon receipt of the patient's information but could have been accomplished asynchronously. The term interactive does not refer to patient-to-patient or patient-to-provider interaction in Internet support groups or chat rooms.

Internet-mediated disease monitoring systems were defined as home health monitoring systems (computers and/or home health monitoring devices and peripherals such as blood pressure cuffs or video monitors) that transmitted health information about a patient to a care provider through a medium that engaged the Internet in some aspect of the data transmission. Thus, the Internet could have been used as the whole system for exchanging information or as a part of a larger system.

\section{Literature search terms and strategies}

Table 1 lists the 13 databases searched for this project. Bibliographic hand searching from relevant articles was also conducted. Table 2 provides search terms. Articles published between January 1, 2000, and December 31, 2006, were included. 


\section{JRIPE}

70

The Role of the Internet in Homebased Patient Monitoring

Nicol, Bush, \& Balka

Journal of Research in Interprofessional Practice and Education

Vol. 1.1

October, 2009
Journal of Research in Interprofessional Practice and Education

Table 1

\section{Databases searched in review}

\begin{tabular}{lc} 
Academic Search Premier & ACM Digital Library \\
CAB Direct (CAB Abstracts \& Global Health) & CINAHL \\
\hline Cochrane Central Register of Controlled Trials (CENTRAL) & Elsevier \\
\hline Humanities \& Social Sciences Index & IEEE Xplore \\
Library, Information Science, \& Technology Abstracts (LISTA) & MEDLINE (OVID) \\
\hdashline PubMed Central & PsychINFO \\
SCOPUS &
\end{tabular}

Table 2

Search terms

\begin{tabular}{|c|c|}
\hline at-home care & at-home treatment \\
\hline chronic disease & $\begin{array}{l}\text { computer (including computer-assisted, } \\
\text { computer enabled, computerized) }\end{array}$ \\
\hline cyber & disease management \\
\hline e-health/e-medicine (with and without hyphen) & home-monitoring \\
\hline interactive & modem \\
\hline monitoring & patient-monitoring \\
\hline randomized controlled trial & remote \\
\hline
\end{tabular}

We do not claim that this is an exhaustive review of all studies of health technologies that employed the Internet in the monit oring of chronic diseases. Given the lack of commonly accepted nomenclature for health information technologies in general and for the specific type of interventions we studied, we cannot state that our search identified every relevant article. Due to the wide variety of health outcome data provided in the studies, we were also not able to aggregate results and conduct a meta-analysis. Other authors, particularly Griffiths [13], have been criticized for using the term systematic review in the context of a review of a technology [14]. As she asserted in her response to this charge, a review can be comprehensive without being exhaustive. We consider this review to be comprehensive in this sense.

\section{Data extraction}

Multiple investigators read the titles and abstracts generated by the search of the databases and, using agreed-upon eligibility criteria (see Table 3), selected relevant articles for more detailed review. Four hundred and fifty-four (454) abstracts were considered. Forty-three (43) of these were selected and the articles read in detail; of these, 17 articles met inclusion criteria. 
71

The Role of the Internet in Homebased Patient Monitoring

Nicol, Bush, \& Balka
Journal of Research in Interprofessional Practice and Education

Vol. 1.1

October, 2009
Table 3

\section{Inclusion and exclusion criteria}

\begin{tabular}{|c|c|}
\hline Inclusion & Exclusion \\
\hline Randomized controlled trials & $\begin{array}{l}\text { Observational, prospective, and pilot studies, } \\
\text { comments, discussions }\end{array}$ \\
\hline Chronic physiological condition & Systematic reviews \\
\hline Physiological health outcome measured & $\begin{array}{l}\text { Wellness, mental health, sexually transmitted disease, } \\
\text { sexual dysfunction, and cancer studies }\end{array}$ \\
\hline Information/data transferred over Internet & $\begin{array}{l}\text { Studies using computers programs that are not } \\
\text { facilitated over the internet }\end{array}$ \\
\hline$>10$ subjects receiving intervention & $\begin{array}{l}\text { Studies with numerous treatment conditions but no } \\
\text { controls }\end{array}$ \\
\hline Controls identified at randomization & $\begin{array}{l}\text { Studies where groups were not randomized but } \\
\text { identified during study on the basis of data analysis }\end{array}$ \\
\hline Original data & Study protocols not completed \\
\hline Completed study & Study protocols not completed \\
\hline Publication in English & Publication not in English \\
\hline Publication between January 2000 and December 2006 & \\
\hline
\end{tabular}

\section{Data synthesis}

A standardized audit form was developed to analyze each article. Two team members read the selections, entered data on the form, and met to resolve disagreements. Data was grouped into disease-specific categories and physiological outcomes were described for each condition separately. We also examined nonphysiological outcomes discussed in the studies, including the short- and long-term effectiveness of the interventions, costs, and technology-related issues.

\section{Description of studies}

Table 4 presents the 17 articles that met inclusion criteria. Williamson et al. (2005, 2006) published articles at both 6 and 24 months of their trial $[15,16]$. Because results differed, both articles were included. Two articles focused on asthma, five on diabetes, and five on obesity. Four trials studied cardiovascular diseases (CVDs). One of these, Finkelstein et al. [17], studied multiple conditions, including cardiovascular disease.

Overall, the studies were primarily conducted with adults. They included males and females in approximately equal numbers and engaged participants from diverse ethnic and racial backgrounds. Total study populations ranged from 53 to 1,665 participants, although more than half the studies enrolled fewer than 200 participants at baseline. Two trials were conducted in Korea, one in the United Kingdom, one in 
72

The Role of the Internet in Homebased Patient Monitoring

Nicol, Bush, \& Balka

Journal of Research in Interprofessional Practice and Education

Vol. 1.1

October, 2009
Table 4

\section{Overview of included studies}

\begin{tabular}{|c|c|c|c|c|c|c|c|}
\hline Author(s) & Condition & Pop. & $\begin{array}{c}\text { Pop. } \\
\text { Description }\end{array}$ & Length & $\begin{array}{c}\text { Intervention } \\
\text { Type }\end{array}$ & Comparison & $\begin{array}{c}\text { Cost } \\
\text { Analysis }\end{array}$ \\
\hline $\begin{array}{l}\text { Benatar } \\
\text { [19] }\end{array}$ & $\begin{array}{c}\text { Cardiovascular } \\
\text { disease* }\end{array}$ & $\begin{array}{l}216 \\
\text { adults }\end{array}$ & $\begin{array}{c}\text { Male and female, } \\
\text { predominantly } \\
\text { African-American }\end{array}$ & $\begin{array}{c}12 \\
\text { months }\end{array}$ & $\begin{array}{l}\text { Unique home monitoring } \\
\text { device to an Internet server } \\
\text { accessed by HCP (Avidcare) }\end{array}$ & Usual care & Yes \\
\hline $\begin{array}{c}\text { Cleland } \\
{[20]}\end{array}$ & $\begin{array}{l}\text { Cardiovascular } \\
\text { disease* }^{*}\end{array}$ & $\begin{array}{l}426 \\
\text { adults }\end{array}$ & $\begin{array}{l}\text { Predominantly } \\
\text { male }\end{array}$ & $\begin{array}{c}15 \\
\text { months }\end{array}$ & $\begin{array}{l}\text { Unique system with modem- } \\
\text { enabled wireless peripheral } \\
\text { devices to an Internet server } \\
\text { accessed by HCP (TEN-HMS) }\end{array}$ & $\begin{array}{l}\text { Usual care or } \\
\text { nurse telephone } \\
\text { support }\end{array}$ & No \\
\hline $\begin{array}{c}\text { Finkelstein } \\
\text { [5] }\end{array}$ & $\begin{array}{c}\text { Cardiovascular } \\
\text { disease, } \\
\text { chro COPD } \\
\text { care }\end{array}$ & $\begin{array}{c}53 \\
\text { adults }\end{array}$ & $\begin{array}{l}\text { Male and } \\
\text { female }\end{array}$ & $\begin{array}{c}6 \\
\text { months }\end{array}$ & $\begin{array}{l}\text { Web access enhanced with } \\
\text { remote video visit platform } \\
\text { with peripheral monitoring } \\
\text { equipment }\end{array}$ & $\begin{array}{l}\text { Usual care } \\
\text { or remote } \\
\text { video visit }\end{array}$ & Yes \\
\hline $\begin{array}{l}\text { Guendelman } \\
\text { [18] }\end{array}$ & Asthma & $\begin{array}{c}134 \\
\text { children } \\
(8-16)\end{array}$ & $\begin{array}{c}\text { Male and female, } \\
\text { predominantly } \\
\text { African American }\end{array}$ & $\begin{array}{c}3 \\
\text { months }\end{array}$ & $\begin{array}{l}\text { Unique home monitoring } \\
\text { device to an Internet server } \\
\text { accessed by HCP (Health } \\
\text { Buddy) }\end{array}$ & Usual care & Yes \\
\hline $\begin{array}{l}\text { Harvey-Berino } \\
\text { [25] }\end{array}$ & Obesity & $\begin{array}{l}122 \\
\text { adults }\end{array}$ & $\begin{array}{l}\text { Predominantly } \\
\text { female }\end{array}$ & $\begin{array}{c}18 \\
\text { months }\end{array}$ & $\begin{array}{c}\text { Web-based system with moni- } \\
\text { toring and chat room support } \\
\text { group }\end{array}$ & $\begin{array}{c}\text { Minimal in-person } \\
\text { support or frequent } \\
\text { in-person support }\end{array}$ & No \\
\hline $\begin{array}{l}\text { Harvey-Berino } \\
\text { [24] }\end{array}$ & Obesity & $\begin{array}{l}255 \\
\text { adults }\end{array}$ & $\begin{array}{l}\text { Predominantly } \\
\text { female }\end{array}$ & $\begin{array}{c}18 \\
\text { months }\end{array}$ & $\begin{array}{l}\text { Web-based system with } \\
\text { monitoring and chat room } \\
\text { support group }\end{array}$ & $\begin{array}{c}\text { Minimal in-person } \\
\text { support or } \\
\text { Frequent in-person } \\
\text { support }\end{array}$ & No \\
\hline $\begin{array}{l}\text { Kim } \\
{[29]}\end{array}$ & $\begin{array}{l}\text { Diabetes } \\
\text { - type } 2\end{array}$ & $\begin{array}{l}60 \\
\text { adults }\end{array}$ & Male and female & $\begin{array}{c}3 \\
\text { months }\end{array}$ & Web-based system & Usual care & No \\
\hline $\begin{array}{l}\text { Kwon } \\
{[30]}\end{array}$ & $\begin{array}{l}\text { Diabetes } \\
\text { - type } 2\end{array}$ & $\begin{array}{l}110 \\
\text { adults }\end{array}$ & $\begin{array}{l}\text { Predominantly } \\
\text { male }\end{array}$ & $\begin{array}{c}3 \\
\text { months }\end{array}$ & $\begin{array}{l}\text { Web-based system with } \\
\text { cell technology }\end{array}$ & Usual care & No \\
\hline $\begin{array}{l}\text { McKay } \\
{[23]}\end{array}$ & $\begin{array}{l}\text { Diabetes } \\
\text { - type } 2\end{array}$ & $\begin{array}{l}160 \\
\text { adults }\end{array}$ & $\begin{array}{l}\text { Male and } \\
\text { female }\end{array}$ & $\begin{array}{c}3 \\
\text { months }\end{array}$ & $\begin{array}{l}\text { Web-based system } \\
\text { Web education and } \\
\text { e-counselling (DNet) }\end{array}$ & Web education & No \\
\hline $\begin{array}{c}\text { McMahon } \\
\text { [31] }\end{array}$ & $\begin{array}{c}\text { Diabetes, } \\
\text { non-specific }\end{array}$ & $\begin{array}{l}104 \\
\text { adults }\end{array}$ & $\begin{array}{l}\text { Predominantly } \\
\text { male }\end{array}$ & $\begin{array}{c}12 \\
\text { months }\end{array}$ & Web-based system & Usual care & No \\
\hline $\begin{array}{c}\text { Rasmussen } \\
\text { [22] }\end{array}$ & Asthma & $\begin{array}{l}300 \\
\text { adults }\end{array}$ & $\begin{array}{l}\text { Predominantly } \\
\text { female }\end{array}$ & $\begin{array}{c}6 \\
\text { months }\end{array}$ & Web-based system & $\begin{array}{l}\text { Usual care } \\
\text { or specialist }\end{array}$ & No \\
\hline $\begin{array}{l}\text { Shea } \\
{[21]}\end{array}$ & $\begin{array}{r}\text { Diabetes, } \\
\text { non-specific }\end{array}$ & $\begin{array}{l}1665 \\
\text { adults }\end{array}$ & $\begin{array}{l}\text { Predominantly } \\
\text { female, mostly } \\
\text { White or } \\
\text { Hispanic }\end{array}$ & $\begin{array}{c}12 \\
\text { months }\end{array}$ & $\begin{array}{l}\text { Unique home monitoring } \\
\text { device with an Internet server } \\
\text { and video (IDeatel) }\end{array}$ & Usual care & Yes \\
\hline $\begin{array}{l}\text { Southard } \\
\text { [28] }\end{array}$ & $\begin{array}{c}\text { Cardiovascular } \\
\text { disease }\end{array}$ & $\begin{array}{l}104 \\
\text { adults }\end{array}$ & $\begin{array}{c}\text { Male and female, } \\
\text { predominantly } \\
\text { White }\end{array}$ & $\begin{array}{c}6 \\
\text { months }\end{array}$ & $\begin{array}{l}\text { Web-based system } \\
\text { with Web education }\end{array}$ & Usual care & Yes \\
\hline $\begin{array}{l}\text { Tate } \\
\text { [26] }\end{array}$ & Obesity & $\begin{array}{l}192 \\
\text { adults }\end{array}$ & $\begin{array}{l}\text { Predominantly } \\
\text { White females }\end{array}$ & $\begin{array}{c}12 \\
\text { months }\end{array}$ & \begin{tabular}{|} 
Web-based monitoring of \\
weight, caloric intake, and \\
exercise plus e-counselling \\
Web-based education, mini-
\end{tabular} & $\begin{array}{l}\text { mal weight } \\
\text { monitoring }\end{array}$ & No \\
\hline $\begin{array}{l}\text { Tate } \\
{[27]}\end{array}$ & Obesity & 91 adults & Male and female & 6 months & $\begin{array}{c}\text { Web-based system with Web } \\
\text { education }\end{array}$ & $\begin{array}{l}\text { Web-based } \\
\text { education }\end{array}$ & No \\
\hline $\begin{array}{c}\text { Williamson } \\
{[15,16]}\end{array}$ & Obesity & \begin{tabular}{|c|}
57 children \\
$(11-15)$ \\
and \\
parents
\end{tabular} & $\begin{array}{c}\text { African-American } \\
\text { girls and their } \\
\text { parents }\end{array}$ & $\begin{array}{l}6 \text { and } 24 \\
\text { months }\end{array}$ & $\begin{array}{l}\text { Web-based system plus educa- } \\
\text { tion and email counsellor }\end{array}$ & $\begin{array}{l}\text { Web-based } \\
\text { education }\end{array}$ & No \\
\hline
\end{tabular}


73

The Role of the Internet in Homebased Patient Monitoring

Nicol, Bush, \& Balka

Journal of Research in Interprofessional Practice and Education

Vol. 1.1

October, 2009
Denmark, and the remaining 13 in the United States. Duration of the studies varied considerably: four trials lasted only three months, nine between six months and one year, and only four ran for longer than one year.

Thirteen trials employed disease monitoring systems where patients used a home computer and an Internet connection to enter health data. The remaining four trials $[18,19,20,21]$ used commercially available, "off the shelf" monitoring devices, such as the Health Buddy ${ }^{\mathrm{TM}}$, which were connected to home telephones and accessed the Internet to relay information. These devices could be programmed to ask questions, prompt responses, and provide information.

All trials included measures of physiological outcomes specific to the disease or condition studied, such as changes in blood glucose levels for diabetes patients and changes in weight or body mass index (BMI) for obesity patients. Table 5 provides further details on outcome measures.

\section{Control groups and usual care}

While most studies compared their intervention groups to groups receiving "usual care," this was not universal. Cleland [20], Finkelstein [17], and Rasmussen [22], for example, randomized to multiple comparison groups, including groups receiving usual care. Even though usual care in the form of outpatient management has been established for diabetes, McKay [23] randomized subjects into three groups-those receiving information only via the Internet, those receiving information and peer support via the Internet, and those receiving information with a personal self-management coach via the Internet. He did not include a group receiving outpatient management, the current protocol for usual care, stating that he chose the "information-only condition" as the control group because he wanted to separate those receiving access to information only from his two other intervention conditions and because offering controls "something of potential benefit" p. 37 (a computer and Internet connection) would "secure high levels of participation in follow-up assessments and control for the Hawthorne effect" p. 37. In the five obesity studies, the comparison groups also varied widely because usual care has not been established for the treatment of obesity. Harvey-Berino [24,25] studied results from three study conditions: frequent in-person support, minimal in-person support, and Internet support. Tate [26] compared a basic Internet education group to an Internet plus behavioural e-counselling group, and Tate [27] compared Internet education to Internet behavioural therapy groups. Williamson $[15,16]$ randomized participants to Internet and non-Internet groups.

\section{Physiological outcomes of the Internet intervention by disease (see Table 5)}

\section{Asthma}

Both asthma studies included in this review were of a short duration ( 3 and 6 months). Rasmussen [22] employed a home computer/Internet-based asthma management plan and compared three groups: asthma management by a general practitioner (usual care), asthma treatment by specialist in an outpatient clinic, and asthma treatment by 
74

The Role of the Internet in Homebased Patient Monitoring

Nicol, Bush, \& Balka

Journal of Research in Interprofessional Practice and Education

Vol. 1.1

October, 2009
Table 5

\section{Primary outcome assessment measures}

\begin{tabular}{|l|l|l|}
\hline Disease & Health-Specific Outcome & Other Measures \\
\hline Asthma & $\begin{array}{l}\text { Peak flow measures, forced expiratory vol- } \\
\text { ume (FEV), number of asthma symptoms }\end{array}$ & $\begin{array}{l}\text { Medication compliance, visits and calls to } \\
\text { HCP }\end{array}$ \\
\hline $\begin{array}{l}\text { Cardiovascular } \\
\text { disease }\end{array}$ & $\begin{array}{l}\text { Blood pressure and heart functioning, cho- } \\
\text { lesterol, number of cardiac events, weight } \\
\text { loss, mortality, symptom severity }\end{array}$ & $\begin{array}{l}\text { Hospitalizations and emergency room vis- } \\
\text { its, duration of hospital stay, medication } \\
\text { compliance, discharge to a different level } \\
\text { of care }\end{array}$ \\
\hline Diabetes & $\begin{array}{l}\text { Blood glucose levels (Hba1c), lipid levels, } \\
\text { BMI, blood pressure }\end{array}$ & \begin{tabular}{l} 
Dietary behavior \\
\hline Obesity
\end{tabular} \\
\hline BMl, weight, waist circumference & $\begin{array}{l}\text { Dietary intake, exercise frequency and } \\
\text { duration }\end{array}$ \\
\hline
\end{tabular}

Note: ${ }^{*}$ Chronic heart failure ; ${ }^{* *}$ Congestive heart failure

specialist using an Internet-based management tool. This research found that the Internet-based system improved lung functioning and airway responsiveness over both comparison groups. Guendelman's [18] team compared use of the Health Buddy ${ }^{\mathrm{TM}}$ to a control group keeping an asthma diary and found that peak flow measures improved and the odds of experiencing limitations to activity decreased in the study group compared to the comparison group.

Both studies found increased medication compliance in the intervention groups. In her intervention group, Rasmussen [22] also noted increases in the number of visits to healthcare providers (HCPs) as well as the number of reported side effects in her two treatment conditions and speculated that this was due to increased medication compliance. This study concluded that the intervention produced better control of asthma but at the cost of more frequent monitoring, higher consumption of medications, and increased side effects. Guendelman [18] found that hospitalization and rates of emergency department visits did not differ significantly by treatment group, but patients in the intervention group made significantly fewer urgent calls to healthcare providers than those in the control group $(\mathrm{p}=.05)$. This research also found that subjects' use of the Health Buddy ${ }^{\mathrm{TM}}$ exceeded use of the asthma diary, although engagement in both treatment modalities declined toward the end of the study. The authors speculated this was likely due, for Health Buddy ${ }^{\mathrm{TM}}$ users, to saturation with the educational messages provided through the device [18].

\section{Cardiovascular disease}

Four studies addressed patients with cardiovascular diseases. Cleland et al's [20] study found that patients using an Internet-based monitoring system (TEN-HMS) and those using nurse telephone support (NTS) had significantly decreased mortality rates com- 
75

The Role of the Internet in Homebased Patient Monitoring

Nicol, Bush, \& Balka
Journal of Research in Interprofessional Practice and Education

Vol. 1.1

October, 2009 pared to patients receiving usual care (29\% and $27 \%$ versus $45 \%$ ) over one year, without an increase in hospital admissions. The number of hospital admissions was similar between patients but the TEN-HMS patients had shorter lengths of stay in hospital.

Although Finkelstein et al's [17] study involved only 24 CVD patients, the study found that ongoing monitoring, coupled with video conference and home nursing visits, helped to reduce discharge to a higher level of care (from home to a nursing home or hospital). No differences were found in mortality over six months. Southard et al.s [28] study of cardiac rehabilitation patients found a significant reduction in the number of cardiac events among those involved in an Internetbased management system compared to those receiving usual care. Benatar [19] found that an Internet-mediated nurse telemonitoring system decreased hospital admission rates in the first three months of the program compared to home nurse visits, although the difference lost statistical significance by the end of 12 months [19]. Thus, while the specific results of the trials varied, all CVD studies showed that the Internet-based interventions had positive effects, especially in the short run.

\section{Diabetes}

Four studies $[29,30,20,31]$ compared Internet-mediated interventions to usual care, while McKay [23] compared monitoring to other interventions. Because the same physiological outcomes (blood glucose levels) were measured across these studies, we were able to directly compare specific test results (see Table 6) and found that the interventions generally showed positive impacts on health outcomes.

\section{Table 6}

\section{Blood glucose results of sampled diabetes studies}

\begin{tabular}{|c|l|c|}
\hline Author & Findings & Study Duration \\
\hline $\begin{array}{c}\text { Kim } \\
{[29]}\end{array}$ & $\begin{array}{l}1.15 \% \text { mean decrease in subjects versus } 0.07 \% \text { decrease in comparison } \\
\text { group }(\mathrm{p}=0.005)\end{array}$ & 3 months \\
\hline $\begin{array}{c}\text { Kwon } \\
{[30]}\end{array}$ & Final blood glucose values 6.94 versus $7.62 \%(\mathrm{p}<0.001)$ & 3 months \\
\hline $\begin{array}{c}\text { McKay } \\
{[23]}\end{array}$ & No significant differences found & 3 months \\
\hline $\begin{array}{c}\text { McMahon } \\
{[31]}\end{array}$ & $\begin{array}{l}\text { Subjects had a greater decline in blood glucose over time than controls } \\
(\mathrm{P}<0.05) \text {. At } 12 \text { months, comparison group had }-1.2(+/-1.4) \% \text { and } \\
\text { subjects had }-1.6(+/-1.4) \%\end{array}$ & 12 months \\
\hline $\begin{array}{c}\text { Shea } \\
{[21]}\end{array}$ & $\begin{array}{l}0.18 \% \text { decrease in subjects }(\mathrm{p}=0.006) \text { and } 0.32 \% \text { in subgroup with } \\
\text { blood glucose }>=7 \%(\mathrm{p}=0.002)\end{array}$ & 12 months \\
\hline
\end{tabular}

\section{Obesity}

The obesity trials were generally the longest of this review, running between one and two years. Whether because of the length of the studies or other factors, these trials 
76

The Role of the Internet in Homebased Patient Monitoring

Nicol, Bush, \& Balka
Journal of Research in Interprofessional Practice and Education

Vol. 1.1

October, 2009 showed the poorest health outcome results in our sample. For example, studies that showed positive effects in terms of weight loss or reductions in BMI in the initial phases of the intervention showed that these results were not sustained over the course of the study, a common result of other types of weight loss programs [32]. In particular, Williamson [16] studies of African-American adolescent girls showed that significant results at six months had disappeared by the end of the two-year period.

Most of the weight-loss interventions featured a range of Web-enabled activities from chat rooms to diet coaches and compared these against each other rather than against an established weight-loss program such as Weight Watchers ${ }^{\mathrm{Tm}}$. The absence of a standard definition of usual care, the lack of clear protocols for control groups, and the layering of interventions across treatment groups made it difficult to identify which activities may have produced which results. For example, Tate first trial [27] showed the most positive impact of Internet monitoring. Unfortunately, it was only run for six months. Her second study, which ran for a year, compared a Web education program with minimal monitoring to a more comprehensive program of monitoring plus e-counselling and found that both treatment and comparison groups lost the majority of their weight in the initial phases of the studies, with the e-counseling group losing more than the comparison groups. Interestingly, the authors themselves attributed the increased initial weight loss to the e-mail counselling, not the Internet monitoring.

\section{Effectiveness over time}

Of the four studies conducted for over one year [15,20,23,24], only Cleland [20] found significant long-term effects of the intervention. The others, all conducted with obesity patients, found no long-term effects of the interventions. Indeed, Williamson [15], who measured the same population twice, found that significant weight loss at six months had disappeared by 24 months. The other 13 studies (see Table 4) were conducted for one year or less, making it impossible to determine how effective the interventions might have been had they run over the much longer course of treatment normally associated with the management of chronic diseases.

\section{Technological issues and the role of the Internet}

Few studies provided information about the challenges experienced when designing and implementing monitoring programs using the Internet. Of those that did, concerns about the Internet as a platform for health interventions fell into four areas:

- technological and environmental adaptability

- attrition from Internet interventions

- work practice and communication issues

- cost assessments

\section{Technological and environmental adaptability}

Shea [21], whose article provided the best overview of these issues, employed a Webenabled computerized home telemonitoring unit (HTU) as well as wireless periph- 
77

The Role of the Internet in Homebased Patient Monitoring

Nicol, Bush, \& Balka

Journal of Research in Interprofessional Practice and Education

Vol. 1.1

October, 2009 eral devices to monitor patients' blood glucose levels. This study reported high acceptance of the technology among subjects from very diverse backgrounds. It also reported that loss to follow-up was due primarily to factors specific to the home telemonitoring unit's size and the challenges patients had in learning to use it [21]. This research also reported problems setting up the systems due to the poor quality of some patients' telephone service. In a similar vein, McMahon [31] speculated that access to the Internet and the computer training provided to trial participants might not be widely available to others, and thus might affect the generalizability of his results. McKay et al. [23] were concerned about the digital divide and specifically restricted the study sample to participants who did not have Internet access at their homes or workplaces.

Cleland [20] and Finkelstein [5] identified patients' home environments and the availability of technical support to install and fix equipment as important. Cleland's [20] study found that participants' acceptance and ability to cope with complicated technology in their own homes was high. Finkelstein [5] used a unique combination of technologies (a Web-enabled ViaTV system plus peripheral monitoring devices) to monitor patients with CVD. Inclusion in this trial required that patients live in a "technically functional home environment" that included adequate lighting, close proximity of telephone and television lines, and "manageable clutter" (p. 130). Although the number of people excluded because of these factors was not discussed, Finkelstein [5] did observe that the problem his elderly subjects faced in terms of technological adaptability was not their inability to use the technology but their "reluctance to try it on their own" (p. 136).

\section{Attrition from Internet interventions}

A number of studies showed that participants' use of the devices, computers, and websites associated with the intervention decreased over time. Williamson's [15] subjects' use of the Web-monitoring weight loss program dropped dramatically after one year. Tate's 2003 study [24] found that log-ins to their website dropped in both the intervention and control groups over time. Guendelman [18] found significant attrition after three months. Assessments of the reasons for high attrition rates varied. McKay [23] found that attrition was a problem across all age and income subgroups. Harvey-Berino [24] noted that the Internet-support group showed significantly higher levels of attrition than the comparison groups, leading her to hypothesize that Internet-mediated interventions were "not universally appealing to everyone with Internet connections" (p. 328). Regrettably, no one seems to have asked participants the reasons they left the studies or to have reported it if they did.

\section{Work practice and communication issues}

No authors discussed the changes to the standard work practices of physicians, nurses, case managers, and technicians occasioned by their interventions, nor did any authors describe how work practices varied across different interventions in the same study. In fact, only Benatar [19], Cleland [20], Southard [28], and Guendelman 
78

The Role of the Internet in Homebased Patient Monitoring

Nicol, Bush, \& Balka

Journal of Research in Interprofessional Practice and Education

Vol. 1.1

October, 2009
[18] discussed work practices in any detail or speculated about the function of work practices in the success of the intervention. Benatar [19] credited the expanded role of the Advanced Practice Nurse as one reason for the success of the nurse telemanagement (intervention) condition over the home nurse visits (usual care) but did not discuss how nursing practice changed to accomplish this. Cleland [20] discussed the time and costs of usual nursing care and said little about how nursing practice changed to accomplish his telemedical interventions. Guendelman [18] attributed the decline in asthma symptoms in both control and treatment groups to several factors, including the "consistent, standardized" educational program practised during the study, the availability of the nurse coordinator, and the contemporaneous dissemination of revised asthma guidelines between providers, but the authors never discussed how these factors may have led to enhanced care or how the care delivered by the nurse coordinator differed from usual care practices. McKay [23] was the sole author to acknowledge the role of work practices in his trial, stating that one of the motives for his study was to determine whether the success of a previous diabetes treatment intervention that involved an "extraordinary amount of support, healthcare professional contacts and attention . . . to participants" (pp. 33-34) could be replicated with fewer staff serving patients from a wider variety of clinics. Unfortunately, he posed but did not answer the question.

Overall, little attention was paid to assessing communication between chronic disease management providers, even though many of the interventions were described as providing communication channels between care teams. For example, Benatar [19] study employed "an advanced practice nurse [who] worked collaboratively with a cardiologist" (pp. 348) and cited this factor as a strength of the study, although no evaluation of the interprofessional communication process was included in the results. Southard's intervention provided subjects Web access to a multidisciplinary care team including a dietician, nurse case manager, physicians, and a psychologist. Although communication patterns were not one of the results analyzed from the intervention, Southard [28] did identify that one of the problems with her study was the "low level of bidirectional communication between case managers and physicians", (p. 346). Guendelman [18] noted that one of the limitations of her study was that children's healthcare providers were unable to consistently access data generated by the Health Buddy ${ }^{\mathrm{TM}}$ intervention (although this problem has apparently been solved with subsequent programming). This type of technological problem may hinder care team communication. Additionally, rather than reducing provider workload, technological problems may lead to increased work and frustration when communication breakdowns or system failures occur. Finally, Cleland's [20] results indicated that increased patient monitoring either by nurses or home telemonitoring provided "better organization of care and patient support," although this study did not elaborate on how communication or organization between the care management team was facilitated. He concludes that staff training on telemonitoring systems would improve effectiveness and that "improvements in devices, communication and data processing for decision support" (p. 1664) would increase the benefits of telemonitoring. 
79

The Role of the Internet in Homebased Patient Monitoring

Nicol, Bush, \& Balka

Journal of Research in Interprofessional Practice and Education

Vol. 1.1

October, 2009

\section{Cost assessments}

Only six studies provided specific information about costs associated with such systems. Given that computer-enabled home monitoring systems have been touted for their cost saving potential, the silence of most of the authors of our studies on this issue is disturbing.

Among the six authors who did discuss costs, Southard [28] estimated that the net savings in her Internet-based monitoring program were $\$ 1,418$ dollars per person over six months against the costs of usual care. Benatar et al. [19] (2003) found that hospital readmission costs at 12 months were lower in the AvidCare ${ }^{\mathrm{TM}}$ home monitoring system $(\$ 541,378)$ versus the home nurse visit group $(\$ 677,710)$, although the difference was found not to be statistically significant. Finkelstein [5] broke down costs by visit, finding that a home visit by a nurse cost $\$ 48.27$ mean per visit, virtual visits with monitoring $\$ 33.11$ mean per visit, and virtual visits alone $\$ 22.11$ mean per visit. His cost analysis also included the costs of technical support and travel time. Guendelman [18] stated that the cost of using the Health Buddy ${ }^{\mathrm{TM}}$ consisted of a one-time implementation fee, patient activation fees that varied by disease and patient volume (estimated as ranging from US\$20 to $\$ 45$ in 2000), and "additional costs [that] involve the case manager and depend on caseload" (p. 120), but gave no figures for these latter costs. No studies explicitly discussed the costs of providing computers and Internet access to study participants.

On the other hand, two studies that discussed costs raised interesting questions implicitly. Rasmussen [22], for example, found that the higher consumption of medication in the intervention group caused more side effects and more unscheduled visits to providers than subjects in the control group. Benatar [19] looked at costs associated with readmissions and length of hospital stay and found the telemonitoring intervention reduced hospital readmission rates in the short run but this benefit lost statistical significance at 12 months, "possibly reflecting regression to the mean as fewer patients [remained] free of hospitalizations" (p. 351).

\section{Discussion}

Because of the short time frame of most of the studies reviewed, it is difficult to generalize about the potential long-term effects of Internet-based systems for chronic disease management. Short duration of treatment may be problematic whenever any disease or condition is studied in an RCT, but it is especially so for chronic diseases. Longer-term studies are critically needed to assess the real-world effectiveness and "return on investment" rates of home monitoring interventions over several years.

More problematic from a policy point of view, none of the articles speculated on the potential downstream consequences of integrating Internet-based home monitoring devices into the protocols for chronic disease management on a scale larger than that of their randomly controlled trials, although their studies raised questions in this regard. Rasmussen [22] for example, found that asthma patients who took their medications more faithfully accessed formal care more often than patients whose treatment was less frequently monitored. Could this mean that one of the unintended consequences of continual monitoring and greater medication compli- 
80

The Role of the Internet in Homebased Patient Monitoring

Nicol, Bush, \& Balka

Journal of Research in Interprofessional Practice and Education

Vol. 1.1

October, 2009 ance might be an increase in visits to formal care providers rather than a decrease in such visits? Further, while authors of our studies generally showed that nurse travel time and expenses of home visits decreased with home monitoring interventions, they did not show whether costs increased elsewhere in the system, in, for example, maintaining the network and computers and monitoring the patients.

The unexamined questions posed by these issues are significant. For example, if Internet-based home monitoring of chronic diseases is to become commonplace, monitoring stations will need to operate $24 / 7$ for certain conditions and will need to be staffed with trained personnel. The data derived from patients reporting specific physiological outcomes will need to be organized and communication between care team members coordinated. Monitoring devices themselves will need to be installed, repaired, and upgraded both at the system's headquarters and in patients' homes. Computer technicians, who generally lack medical training, will find themselves in the homes of very sick people, knowing how to repair equipment but not necessarily how to care for people. Liability issues may arise when equipment fails, electricity grids overload, and networks crash. Health authorities may save money on treatment by care providers only to spend it transporting technicians, establishing systems to handle volumes of information, and setting up emergency response centres. In those studies that looked at these variables, there were few lasting, statistically significant differences in rates of hospitalization and clinic visits between telemedicine interventions and nurse visits. Thus, it is important for health policy-makers to look not just at how home monitoring systems can save on current, known costs such as hospitalizations and home nurse visits, but also at how home monitoring systems may shift costs to different sectors and create new cost centres.

The lack of attention paid to understanding how healthcare professionals can use these new technologies is also troubling. On first glance, such technologies appear to create new avenues for sharing patient data, particularly in cases where healthcare providers may not reside in the same geographic location. However, research in related fields has found that the Internet can also hinder communication, requiring more time through asynchronous discussions and creating opportunities for misunderstandings between professionals [36]. Understanding of how disease monitoring programs operate between professionals may be fundamental to both the success of such platforms and the optimal management of patient care.

The issues of geographic location and the nature of patients' home environments may also be of concern for those looking to implement Internet-mediated systems on a broad scale. Shea [21], for example, experienced problems due to the poor quality of rural phone lines, and Finkelstein [5] had difficulty introducing complex systems into people's cluttered homes.

Finally, due to lack of consistency and comparability of cost data across studies, we can make no meaningful statements about the costs and benefits of the technologies we studied. For all these reasons, policy-makers should employ systemic, wholecost accounting methods to look at the potential cascade of long-term and system-wide effects of Internet-mediated home healthcare technologies. Such a 
81

The Role of the Internet in Homebased Patient Monitoring

Nicol, Bush, \& Balka

Journal of Research in Interprofessional Practice and Education

Vol. 1.1

October, 2009 study is urgently required, so both social and economic impacts of large-scale implementation of home telemonitoring can be assessed.

\section{Limitations of the study}

The lack of standardized terminology for Internet-mediated disease monitoring systems or even for in-home health monitoring devices makes it unlikely that our literature search captured all studies that would have fit our search parameters. Further, by focusing on one ICT platform, the Internet, we excluded studies of some of the newest technologies, such as radio frequency identification (RFID), implanted and hand-held device monitoring systems [33,34] as well as some of the oldest technologies, such as telephones [7] and shortwave radio [35], which might have yielded different results. Given this, the concerns raised in our review, particularly those related to health outcomes, apply only to this subset of systems with Internet components deployed to monitor and manage chronic diseases. They may or may not apply to home monitoring systems in general or to other specific systems using other platforms for monitoring or other intervention. In the future, it may be fruitful to compare Internet-mediated monitoring systems to other forms of intervention to see if the same effects are detected.

\section{Conclusions}

Overall, the Internet-mediated disease monitoring systems we studied did not cause harm or exacerbate the chronic conditions they were engaged to treat. In fact, Internet-based home monitoring systems appear to have had beneficial effects in many aspects of the management of asthma, diabetes, and cardiovascular disease. As to their effectiveness, as assessed by their conformity to the standards of care articulated by the Health Council of Canada, the results are mixed. Certainly patients using the Internet-enabled interventions were actively involved in their own care. Case managers and interprofessional teams, with both specialist and generalist expertise, collaborated on and delivered care across all interventions, and the Internet may have facilitated such collaborations. However, few of the studies in this sample actually assessed or even commented on how collaborative care and interprofessional team management was undertaken.

Because some studies showed subjects increasing medication compliance, making more urgent calls, and having more shorter hospital stays than comparison groups, it is not possible to conclude that Internet-based home monitoring minimized unnecessary visits and (hospital) admissions or reduced costs. Finally, the deployment of monitoring technologies in people's homes was generally well accepted by participants and was certainly less "intensive" than hospitalization. Thus, we conclude that the Internet-mediated home monitoring devices we studied met the Health Council of Canada's standards for "good" chronic disease care.

However, we cannot draw conclusions about their feasibility or long-term, realworld effectiveness. It is difficult, for example, to generalize as to how conducive Canadian patients' home environments are likely to be to the requirements of the monitoring technologies. We also know little about attrition from the studies, boredom thresholds, and message saturation to draw conclusions about patients' long- 
82

The Role of the Internet in Homebased Patient Monitoring

Nicol, Bush, \& Balka
Journal of Research in Interprofessional Practice and Education

Vol. 1.1

October, 2009 term commitment to using the telemonitoring devices. Finally, the costs associated with the monitoring systems themselves and the contributions of technical and programming staff were not well enough documented to assess the financial implications of operating such systems over the long term. We also need to know more about the lived experiences of the healthcare providers, technicians, and, most importantly, of the patients involved in these interventions.

Taken as a whole, the studies underscored the role of Internet-based telemonitoring systems as complements to, rather than replacements for, usual care. The systems appear to be, in Finkelstein's [5] phrase, "a beneficial addition" (p. 133) to the home healthcare that chronically ill patients receive.

More studies of home monitoring technologies are urgently needed to identify the variety of factors and conditions for which Internet-based home monitoring systems can be deployed and those for which they cannot. These studies should:

- include long term follow up, preferably for more than a year if appropriate;

- establish control groups who receive clearly described "usual care";

- address issues of provider work practices and technological availability, adaptability, and reliability;

- address issues of care teams, particularly how these platforms do or do not support integrated chronic disease management and interprofessional communication;

- look at patterns of patient engagement with the technology over time and reasons for any attrition;

- establish common criteria for assessing costs.

Only when such data are available will it be possible to determine if Internet-mediated home monitoring systems will reduce the system-wide costs of managing chronic diseases, as policy-makers so fervently desire, or become beneficial supplements to usual care used to positive clinical effect in specific circumstances.

\section{Acknowledgments}

We would like to thank the Action for Health project (funded by the Social Sciences and Humanities Research Council of Canada's Initiative for a New Economy Collaborative Research Initiative 512-2003-1017); the School of Communications, Simon Fraser University; and the Vancouver Coastal Health Institute for their support of this project. Special thanks to Susan Halley, Anne McCulloch, Susan Currie, David Murphy, Nadine Wathen, Per Lindberg, Pernille Bjorn, Sylvia Roberts, and Mimi Doyle-Waters for their help with various aspects of this project.

\section{Competing interests}

The authors have no competing interests.

\section{Abbreviations}

BMI body mass index

COPD chronic obstructive pulmonary disease 
83

The Role of the Internet in Homebased Patient

Monitoring

Nicol, Bush, \& Balka

Journal of Research in Interprofessional Practice and Education

Vol. 1.1

October, 2009
CVD cardiovascular disease

HCC Health Council of Canada

HCP healthcare provider

HTU home telemonitoring unit

ICT information and communications technology

NTS nurse telephone support

RCT randomized controlled trial

TEN-HMS Trans-European Network-Home-Care Management System

\section{References}

1. World Health Organization. (n.d.). Chronic Diseases and Health Promotion. URL: http://www.who.int/chp/en [August 21, 2007].

2. Statistics Canada. (2004). Household Internet use survey [2003]. The Daily. URL:'htttp://wwww.stat-i ican.ca/Daily/English/1040708/d040708a.htmi [August 22, 2007].

3. Health Council of Canada. (2006). Annual report. URL: ihttp://www.healthcouncilcanada.ca

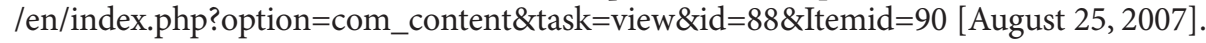

4. Romanow, R.J. (2002). Building on values: The future of health care in Canada. URL: http://publications.gc.ca/pub?id =237274\&sl=0 [August 22, 2007].

5. Finkelstein, S. M., \& Ratner, E. (2006). Managing chronic disease through home telehealth. Minnesota Medicine, 89(11), 42-45.

6. Murray, E., Burns, J., See, T. S., Lai, R., \& Nazareth, I. (2004). Interactive health communication applications for people with chronic disease. Cochrane Database of Systematic Reviews, 18(4), CD004274.

7. Montori, V. M., Guyatt, G. H., Smith, S. A., \& Kudva, Y. C. (2005). Telecare for patients with type 1 diabetes and inadequate glycemic control: Response to Biermann et al. Diabetes Care, 28(1), 229-230.

8. Louis, A. A., Turner, T., Gretton, M., Baksh, A., Cleland, J. G. (2003). A systematic review of telemonitoring for the management of heart failure. European Journal of Heart Failure, 5(5), 583590.

9. Jackson, C. L., Bolen, S., Brancati, F. L., Batts-Turner, M. L., \& Gary, T. L. (2006). A systematic review of interactive computer-assisted technology in diabetes care: Interactive information technology in diabetes care. Journal of General Internal Medicine, 21(2), 105-110.

10. de Lusignan, S., Wells, S., Johnson, P., Meredith, K., \& Leatham, E. (2001). Compliance and effectiveness of 1 year's home telemonitoring: The report of a pilot study of patients with chronic heart failure. European Journal of Heart Failure, 3(6), 723-730.

11. Artinian, N. T., Harden, J. K., Kronenberg, M. W., Vander Wal, J. S., Daher, E., Stephens, Q., et al. (2003). Pilot study of a Web-based compliance monitoring device for patients with congestive heart failure. Heart Lung, 32(4), 226-233.

12. Barnason, S., Zimmerman, L., Nieveen, J., \& Hertzog, M. (2006). Impact of a telehealth intervention to augment home health care on functional and recovery outcomes of elderly patients undergoing coronary artery bypass grafting. Heart Lung, 35(4), 225-233.

13. Griffiths, F., Lindenmeyer, A., Powell, J., Lowe, P., \& Thorogood, M. (2006). Why are health care interventions delivered over the Internet? A systematic review of the published literature [Authors' Reply]. Journal of Medical Internet Research, 8(2), e12.

14. Mayo-Wilson, E. (2006). Health care interventions delivered over the Internet: How systematic was the review. [Letter to the Editor.] Journal of Medical Internet Research, 8(2), e11; author reply e11.

15. Williamson, D. A., Walden, H. M., White, M. A., York-Crowe, E., Newton, R. L. Jr., Alfonso, A., et al. (2006). Two-year Internet-based randomized controlled trial for weight loss in AfricanAmerican girls. Obesity (Silver Spring), 14(7), 1231-1243.

16. Williamson, D. A., Martin, P. D., White, M. A., Newton, R., Walden, H., York-Crowe, E., et al. (2005). Efficacy of an Internet-based behavioral weight loss program for overweight adolescent African-American girls. Eat. Weight Disord, 10(3), 193-203.

17. Finkelstein, S. M., Speedie, S. M., \& Potthoff, S. (2006). Home telehealth improves clinical outcomes at lower cost for home healthcare. Journal of Telemedicine and e-Health, 12(2), 128136. 
84

The Role of the Internet in Homebased Patient Monitoring

Nicol, Bush, \& Balka
Journal of Research in Interprofessional Practice and Education

Vol. 1.1

October, 2009
18. Guendelman, S., Meade, K., Benson, M., Chen, Y. Q., \& Samuels, S. (2002). Improving asthma outcomes and self-management behaviors of inner-city children: A randomized trial of the Health Buddy interactive device and an asthma diary. Archives of Pediatrics and Adolescent Medicine, 156(2), 114-120.

19. Benatar, D., Bondmass, M., Ghitelman, J., \& Avitall, B. (2003). Outcomes of chronic heart failure. Archives of Internal Medicine, 163(3), 347-352.

20. Cleland, J. G. F., Louis, A.A., Rigby, A. S., Janssens, U., \& Balk, A.H.M.M. (2005). Noninvasive home telemonitoring for patients with heart failure at high risk of recurrent admission and death: The Trans-European Network-Home-Care Management System (TEN-HMS) study. Journal of the American College of Cardiology, 45(10), 1654-1664.

21. Shea, S., Weinstock, R. S., Starren, J., Teresi, J., Palmas, W., Field, L., et al. (2006). A randomized trial comparing telemedicine case management with usual care in older, ethnically diverse, medically underserved patients with diabetes mellitus. Journal of the American Medical Informatics Association, 13(1), 40-51.

22. Rasmussen, L. M., Phanareth, K., Nolte, H., \& Backer, V. (2005). Internet-based monitoring of asthma: A long-term, randomized clinical study of 300 asthmatic subjects. Journal of Allergy and Clinical Immunology, 115(6), 1137-1142.

23. McKay, H. G., Glasgow, R. E., Feil, E. G., Boles, S. M., \& Barrera, M. (2002). Internet-based diabetes self-management and support: Initial outcomes from the Diabetes Network Project. Rehabilitation Psychology, 47(1), 31-48.

24. Harvey-Berino, J., Pintauro, S., Buzzell, P., DiGiulio, M., Casey Gold, B., Moldovan, C., et al. (2002). Does using the Internet facilitate the maintenance of weight loss? International Journal of Obesity and Related Metabolic Disorders, 26(9), 1254-1260.

25. Harvey-Berino, J., Pintauro, S., Buzzell, P., Gold, \& E. C. (2004). Effect of Internet support on the long-term maintenance of weight loss. Obesity Research, 12(2), 320-329.

26. Tate, D. F., Jackvony, E. H., \& Wing, R. R. (2003). Effects of Internet behavioral counseling on weight loss in adults at risk for type 2 diabetes: A randomized trial. Journal of the American Medical Association, 289(14), 1833-1836.

27. Tate, D. F., Wing, R. R., \& Winett, R. A. (2001). Using Internet technology to deliver a behavioral weight loss program. Journal of the American Medical Association, 285(9), 1172-1177.

28. Southard, B. H., Southard, D. R., \& Nuckolls, J. (2003). Clinical trial of an Internet-based case management system for secondary prevention of heart disease. Journal of Cardipulmonary Rehabilitation, 23(5), 341-348.

29. Kim, H. S. A randomized controlled trial of a nurse short-message service by cellular phone for people with diabetes. (2007). International Journal of Nursing Studies, 44(5), 687-692.

30. Kwon, H., Cho, J., \& Kim, H. (2004). Establishment of blood glucose monitoring system using the Internet. Diabetes Care, 27(2), 478.

31. McMahon, G. T., Gomes, H. E., Hickson Hohne, S., Hu, T. M, Levine, B. A., \& Conlin, P. R. (2005). Web-based care management in patients with poorly controlled diabetes. Diabetes Care, 28(7), 1624-1629.

32. Weinstein, P. K. (2006). A review of weight loss programs delivered via the Internet. Journal of Cardiovascular Nursing, 21(4), 251-258; quiz 259-260.

33. Kumar, V. S., Wentzell, K. J., Mikkelsen, T., Pentland, A., \& Laffel, L. M. (2004). The DAILY (Daily Automated Intensive Log for Youth) trial: A wireless, portable system to improve adherence and glycemic control in youth with diabetes. Diabetes Technology \& Therapeutics, 6(4), 445453.

34. Korhonen, I., Parkka, J., \& van Gils, M. (2003). Health monitoring in the home of the future. IEEE Engineering in Medicine and Biology Magazine, 22(3), 66-73.

35. Scanailli, C. N, Ahearne, B., Lyons, G. M. (2006). Long-term telemonitoring of mobility trends of elderly people using SMS messaging. IEEE Transactions on Information Technology in Biomedicine, 10(2), 412-413.

36. Teasley, S., \& Wolinsky, S. (2001). Scientific collaborations at a distance. Science, 292(5525), 22542255. 